\title{
INVESTIGATION OF ENERGY USAGE AND EMISSIONS ON PLUG-IN AND HYBRID ELECTRIC VEHICLE
}

\author{
Reza Barmaki, Mohammad Ilkhani, Saman Salehpour
}

Preliminary note

One of the major issues in automotive industry is to develop hybrid electric vehicles (HEVs) as the prime candidate for improving fuel efficiency and emissions reduction. This study addresses the impact of an actual drive pattern and control strategy on the conventional and plug-in hybrid electric vehicles (PHEV). In the first step the development procedure of driving cycle for real condition is proposed. Then effects of driving pattern and energy management strategy as the main factors, which strongly affect the fuel consumption and emission of pollutants, are investigated for HEVs and PHEVs. For this purpose fuzzy logic controller which is optimized with genetic algorithm is developed for energy management system. Then vehicle performance is simulated in ADVISOR. Simulation results demonstrate the effectiveness of the approach for reducing the fuel consumption and emissions. Furthermore, simulation results indicate that PHEVs in comparison to HEVs improve fuel efficiency and reduce emissions in real world driving cycle.

Keywords: emission; fuel consumption; fuzzy controller; genetic algorithm; hybrid vehicle; plug-in hybrid vehicle

\section{Istraživanje potrošnje energije i ispuštanja štetnih plinova kod plug-in i hibridnih električnih vozila}

Prethodno priopćenje Jedan od osnovnih zadataka u automobilskoj industriji je razvoj hibridnih električnih vozila (HEVs) kao primarnog kandidata za poboljšanje učinkovitosti goriva i smanjenje ispušnih plinova. Ovo se istraživanje bavi učinkom aktualnog modela pogona i upravljanja na konvencionalna i plug-in hibridna električna vozila (PHEV). Najprije se predlaže postupak razvoja pogonskog ciklusa za stvarne uvjete. Tada se za HEVs i PHEVs istražuju učinci pogonskog modela i načina upravljanja potrošnjom energije kao glavnih čimbenika koji bitno djeluju na potrošnju goriva i ispuštanje plinova koji zagađuju okolinu. U tu je svrhu za sustav upravljanja energijom razvijen upravljač neizrazite logike optimiziran genetskim algoritmom. Tada je rad vozila simuliran u ADVISOR-u. Rezultati simulacije pokazuju učinkovitost pristupa kojim se smanjuje potrošnja goriva i količina ispušnih plinova. Nadalje, ti rezultati pokazuju da PHEVs u usporedbi s HEVs poboljšavaju učinkovitost goriva i smanjuju količinu ispušnih plinova u stvarnom pogonu.

Ključne riječi: genetički algoritam; hibridno vozilo; ispuštanje plinova; plug-in hibridno vozilo; potrošnja goriva; upravljač neizrazite logike

\section{Introduction}

Hybrid electric vehicles (HEVs) are one of the most viable solutions to the world need for reduction of emissions and fuel consumption. In order to overcome the drawbacks of conventional vehicles, HEVs encompass two energy converters to generate the power required to drive the vehicle. Most typically, the architecture of HEV includes an internal combustion engine (ICE) with an associated fuel tank and an electric machine with its associated energy storage system (battery). The power train system for a parallel HEV incorporates two power drives including an ICE and an electric motor (EM).

Plug in hybrid vehicles are extended version of HEVs to full electric vehicle with no emission and minimum fuel consumption. A PHEV shares the characteristics of both a conventional hybrid electric vehicle having an electric motor and an ICE; and of an all-electric vehicle, having a plug to connect to the electrical grid [1, 2]. A PHEV has the facility to plug-in to a standard electric outlet, and thereby has the potential to displace a significant portion of transportation petroleum consumption using electricity for portions of trips. A key benefit of plug-in hybrid technology is that the vehicle no longer depends on a single fuel source. A unique advantage of plugin hybrid vehicles is their capability to integrate the transportation and the electric power generation sectors to improve the efficiency, fuel economy, and reliability of both systems [3, 4].

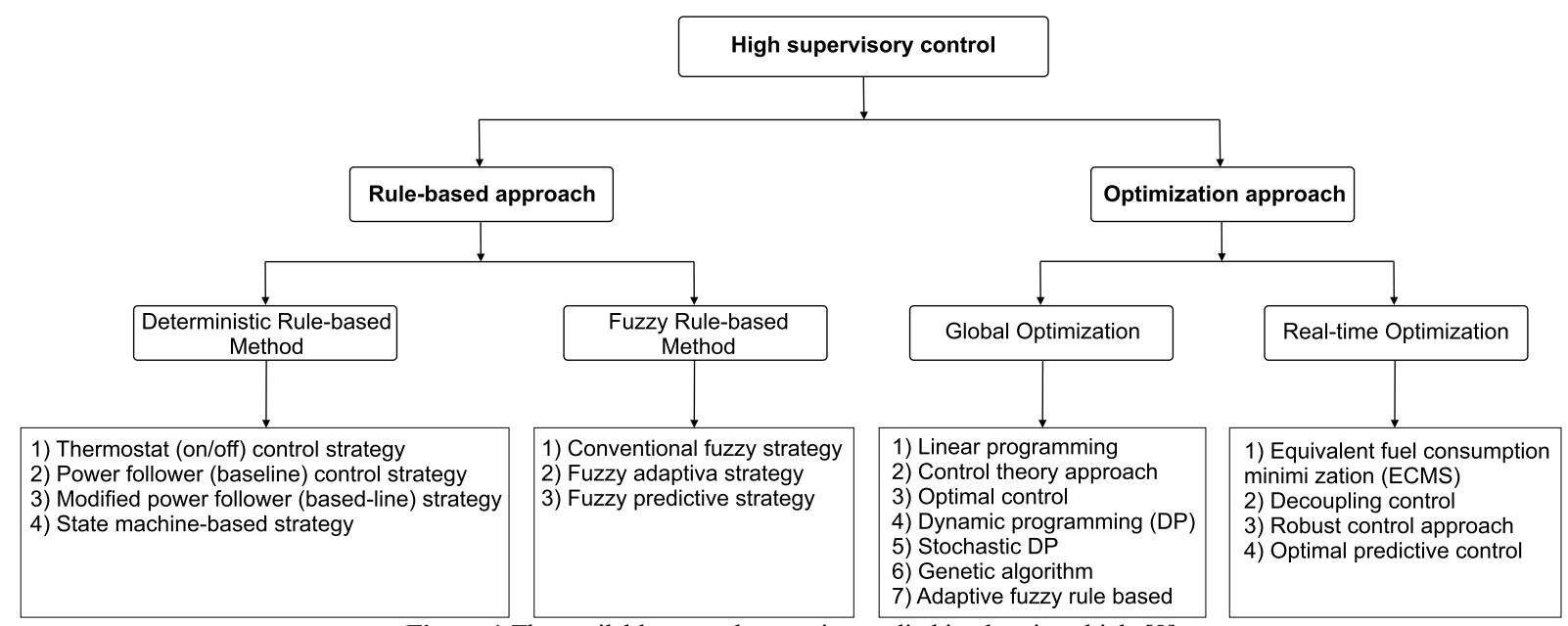

Figure 1 The available control strategies applied in electric vehicle [8] 
HEV and PHEV technology is considered as a successful solution to address some energy efficiency and emissions concerns about vehicles. So, it has been foreseen that by 2035 almost $80 \%$ of all vehicles introduced to the market should be hybrids, diesels, or turbocharged gasoline engines $[5 \div 7]$. PHEVs represent the direction of vehicle development due to excellent fuel economy, environmental advantages and all electric drive capability, which have more battery capacity, different control strategy and could be connected to the electrical grid to charge their batteries.

Driving cycle, energy management system and vehicle type are the most important factors which affect vehicular emissions and fuel consumption. So, in this paper real world driving cycle development procedure is described. Then the effects of control strategy in various driving cycle are investigated. Finally fuel consumption and emissions are compared for PHEV and HEV.

One of the most significant factors in the performance of HEV and PHEV are control strategies, which play an important role in improving energy management of HEVs. Different strategies are used in previous studies. As shown in Fig. 1, they are mainly classified into rule based and optimization approaches [1,8].

Recently, a lot of researches intend to apply intelligent control theory to the control strategy of HEVs and PHEVs such as adaptive control [9], Dynamic Programming (DP) [10] and fuzzy logic controller (FLC) [11]. Song et al. [10], utilized the DP approach to deal with the integrated optimization problem for deriving the best configuration and energy split strategies of a hybrid energy storage system for an electric city bus. Hou et al. [12], Tribioli et al. [13] developed an online optimal control strategy for plug-in hybrid vehicle. They used an algorithm to find the optimal power split between the two sources using a DP. Chen et al. [14] proposed an energy management method for a power-split PHEV by combination of simulated annealing and Pontryagin's Minimum Principle.

Since FLC is simple, adaptation (easy to tune), no need for modelling and has strong robustness, it is suitable for nonlinear control where parameters and/or model are unknown or variable. So many researches used for designing control strategy of HEVs and PHEVs $[15 \div 18]$.

Schouten et al. [18], developed a FLC for HEV with parallel configuration. They used the driver command, the state of charge of the energy storage, and the motor/generator speed, to set of rules in a fuzzy controller, to effectively determine the split between the two power plants in forward modelling.

In $[19,20]$ the application of the genetic algorithm (GA) was described for the optimization of the control parameters in parallel HEV. The objective function was defined so as to minimize the vehicle engine fuel consumption and emissions with regard to vehicle dynamic requirements. In [21], a fuzzy energy management system (EMS) based on driving cycle recognition was proposed to improve the fuel economy of PHEV. The energy management system can recognize the driving cycle based on learning vector quantization.

In [22], two separated controllers using fuzzy logic called Mode Decision and Parallel-driving EMS have been employed to fulfil switching between the series and the parallel modes as well as the instantaneous power distribution. By considering the effect of the driving cycle on the EMS, a fuzzy EMS based on driving cycle recognition has been proposed to improve the fuel economy of a parallel hybrid electric vehicle. The EMS was composed of driving cycle recognition and a fuzzy torque distribution controller, which optimized simultaneously by using particle swarm optimization [21].

In this paper FLC is developed for power splitting in HEV and PHEV. Then genetic algorithm is used for optimal tuning of rules and membership functions to reduce fuel consumption and emission in various driving cycle. Finally, the effects of various combinations of transmission and energy storage systems over various driving cycles on parallel HEV performance are compared.

\section{Vehicle modelling}

Several architectures for HEVs have been conceived and developed, which include series, parallel and powersplit which are shown in Fig. 2.
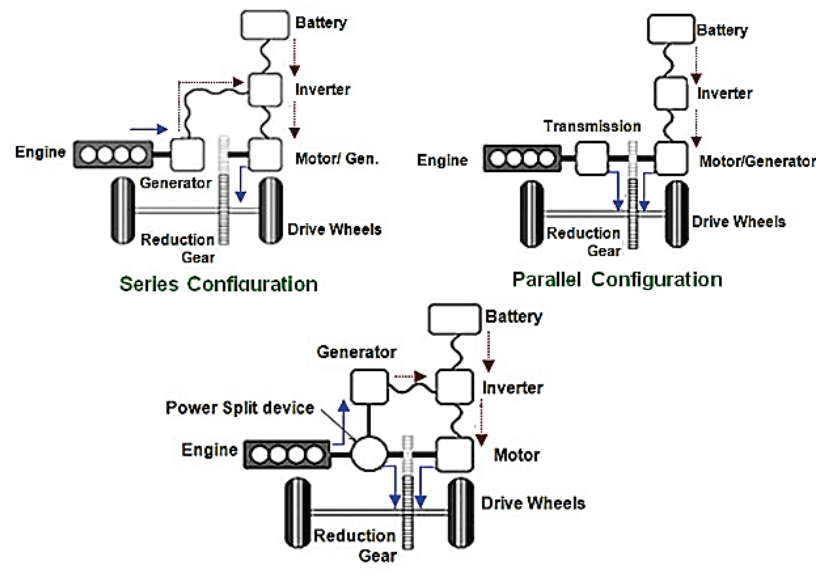

Power Split Configuration

Figure 2 Various configuration of HEV and PHEV [23]

In series architecture, the engine is mechanically coupled to a generator. The generator provides an electric input to the battery stack and from the battery stack, electric power is sent to the motor which is used to generate the tractive power for the vehicle. This configuration is mostly used in small city cars or in diesel engine vehicles.

The parallel architecture allows tractive force to be provided by a combination of the engine and motor. Parallel architectures do, however, allow power to flow backwards through the motor underbraking to recharge the electrical energy storage system; this is known as regenerative braking.

Power-split HEV combines the advantages of series and parallel hybrids by utilizing two electric machines and a combustion engine. In this configuration, the planetary gear set is used to combine the torques of the engine and motor. However power-split has high cost and complexity.

In this paper parallel hybrid vehicle which is sufficient for passenger vehicles and combined driving cycle (including highway and city traffic condition) is 
utilized. Then according to its performance modes optimized FLC by genetic algorithm is developed. Vehicle specifications are presented in Tab. 1.

\begin{tabular}{|c|c|c|c|}
\hline Rolling resistance & 0,015 & \multirow{2}{*}{\multicolumn{2}{|c|}{ Vehicle weight (kg) }} \\
\hline $\begin{array}{l}\text { Aerodynamic } \\
\text { coefficient }\end{array}$ & 0,30 & & \\
\hline Frontal area & 2,1 & Front axle & 716 \\
\hline Wheel radius & 0,30 & Rear axle & 468 \\
\hline Engine & $41 \mathrm{~kW}$ & Distribution & $60 / 40$ \\
\hline Electric motor & $\begin{array}{c}\text { Siemens AC } \\
36 \mathrm{~kW}\end{array}$ & Total & 1184 \\
\hline Lithium-ion battery & $12 \mathrm{~V}-6 \mathrm{Ah}$ & & \\
\hline
\end{tabular}

\subsection{Plug-in HEV}

PHEVs can be charged from external electric power sources. Because of this significant advance in current HEV technology, PHEVs use more electrical power over longer ranges, which is highly economical. Compared with conventional HEVs, PHEVs are equipped with larger battery modules, which can power the vehicle by only using the stored energy charged from the power grid. Also, in comparison to electric vehicles (EV), they use two main sources to propel the vehicle and have smaller energy storage systems. One of the most critical issues for plug-in hybrid two-wheelers is the distance they can run on a single battery charge. For estimating the energystorage requirements and sizing of battery pack, the daily travel distance by a vehicle plays a vital factor [24].

Any plug-in hybrid electric vehicle can be operated in three modes: Charge Depleting (CD), Charge Sustaining (CS) and Blended modes.

In the $\mathrm{CD}$ mode the engine assists the motor only during peak power demand or high acceleration. The battery is depleted until it reaches a particular threshold. The engine assists the vehicle only when the power required is more than the power that the battery can deliver. The battery is only charged in the event of regenerative braking. CS mode uses both internal combustion engine and energy storage system simultaneously so that the state of charge (SOC) is maintained within the prescribed limits.

The combined operation in these two modes is known as a CD-CS strategy, wherein a vehicle is operated in charge depleting mode initially and when the state of charge falls to a particular value, the charge sustaining mode is activated.

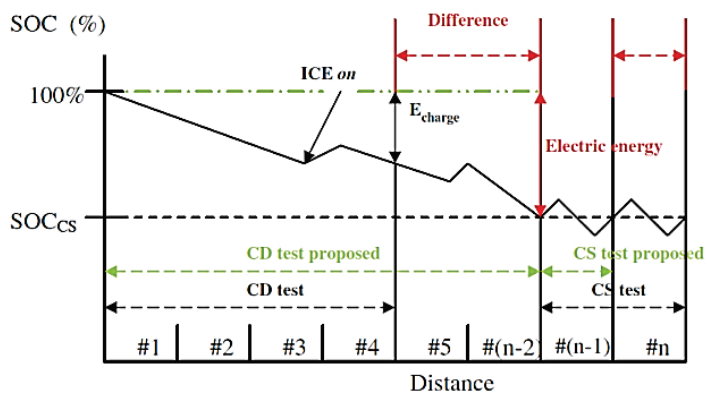

Figure 3 Variation of SOC in blended mode [26]

The vehicle can also be operated in blended mode during which the engine can be triggered more often when compared to the charge depletion operation. This ensures that the vehicle takes longer time to reach charge sustaining operation. In fact, the case of all-electric mode at the beginning of the path is removed, which ensures that the vehicle takes longer time to reach charge sustaining operation. This allows for operating the engine at high efficiency points and utilization of electric energy over a longer range in charge depletion mode which improves fuel economy [25]. Fig. 3 illustrates the blended mode.

\section{Driving cycle development}

A drive cycle is a speed-time sequence produced by different organizations for a certain type of vehicles in a particular environment to represent the real driving pattern to assess the performance of vehicles in various ways, as for example fuel consumption and polluting emissions.

Given that driving patterns vary from city to city and from area to area, the available drive cycles obtained for certain cities or countries are not usually applicable for other cities. Therefore they are unable to represent the actual driving conditions. Real-world driving cycles are derived from the movement of a test vehicle on the road under real traffic conditions.

In this paper a real driving cycle based on the actual traffic condition in Tehran city is developed to conduct the actual measurements of exhaust emissions and fuel consumption of a test passenger vehicle. Then, characteristics of Teh-car cycle are compared with some of light vehicles cycles provided for other countries to investigate the difference between the various driving cycles and traffic conditions. Finally, this cycle is used as input for $\mathrm{HEV}$ and PHEV simulation in backward modelling.

\subsection{Experimental driving cycle development}

Data collection from the test road is the most important activity. Test road (e.g. city, highway, etc.) measured data are the inputs to the drive cycle preparation activity. The driving data include date/time, number of satellites, longitude, latitude, speed and altitude of the vehicle during every second. In this paper, on-board electronic equipment was used and real world traffic data as shown in Fig. 4 were collected, covering almost all the Tehran road network for six month. For this purpose a vehicle fitted with a speed recorder, Global Positioning System (GPS), and accelerometer is driven over selected routes to collect data. The data are subsequently analysed and characterized by the speed-acceleration relative frequency as well as by overall parameters such as average speed and root mean square acceleration.

The GPS system, which is shown in Fig. 4, is a satellite-based navigation system. The GPS Tracker MVT380 system has been used in this study. The data which are recorded every second include some information such as date/time, number of the satellites, longitude, latitude, speed and altitude of the vehicle.

Fig. 4 depicts a sample of measured driving data containing four 1800 (s) driving segments and driving characteristics for Teh-car driving cycle. Also extreme 
segments were removed such as very high top speed segments.
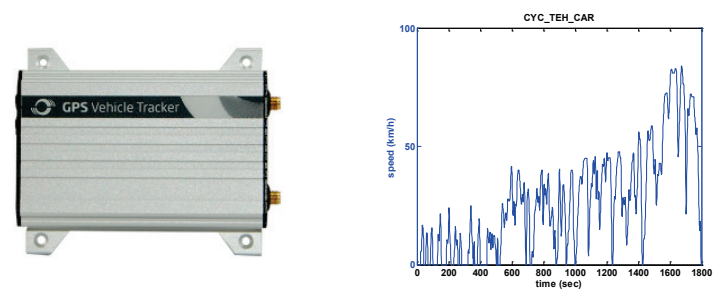

Figure 4 GPS Tracker - MVT380 system and velocity-time driving

\subsection{Driving cycle classification}

There are two major categories of driving cycles, legislative and non-legislative. According to legislative driving cycles, exhaust emissions specifications are imposed by governments for the car Emission Certification. Such cycles are the FTP-75 [27] used in the USA and the NEDC used in Europe. Non-legislative cycles, such as the Hong Kong driving cycle [28], the Sydney driving cycle [29] and the presented Teh-car driving cycle, which are implicated for evaluation of fuel consumption and pollution for various area of traffic conditions.

Also, two categories of driving cycle's development can be found in the literature [30]. Synthesized or modal driving cycles are built by combining different phases of constant acceleration and speed, (like the NEDC and ECE). The other type is derived from actual driving data and is referred as "real world" cycle. Real world driving cycles are developed by recording speed-acceleration profiles while driving on the real world roadway network (often chasing a randomly selected vehicle). Such cycles are the FTP-75 in the US, Hong Kong and Teh-car driving cycles.

Table 2 Comparison of driving cycles features

\begin{tabular}{|l|c|c|c|}
\hline \multicolumn{1}{|c|}{ Driving cycle } & Teh-car & FTP & NEDC \\
\hline Time $(\mathrm{s})$ & 1797 & 2477 & 1184 \\
\hline Distance $(\mathrm{km})$ & 13,42 & 17,17 & 10,93 \\
\hline Max speed $(\mathrm{m} / \mathrm{s})$ & 83,93 & 91,25 & 120 \\
\hline Average speed $(\mathrm{m} / \mathrm{s})$ & 26,87 & 25,82 & 33,21 \\
\hline Max acceleration $\left(\mathrm{m} / \mathrm{s}^{2}\right)$ & 1,71 & 1,48 & 1,06 \\
\hline Average acceleration $\left(\mathrm{m} / \mathrm{s}^{2}\right)$ & 0,45 & 0,51 & 0,54 \\
\hline Ideal time $(\mathrm{s})$ & 302 & 361 & 298 \\
\hline No. stop & 20 & 22 & 13 \\
\hline
\end{tabular}

Proposed Teh-car driving cycle is also one of the Real-World Driving cycles. These cycles are more dynamic, reflecting the more rapid acceleration and deceleration patterns experienced during on road conditions. This more dynamic driving in real world conditions results on higher emissions compared to those under the standard emissions (modal) test cycles. Three different urban drive cycles and their statistics, the US FTP, NEDC and Teh-car are presented in Tab. 2.

\section{Optimized flc development}

The control strategies primarily target the minimization of fuel consumption, while meeting the power demand and also enhancing the drivability. The present work deals with the backward and forward modelling of a parallel PHEV.
Control strategies play an important role in improving vehicle performance and managing energy usage for HEV and PHEV. In this paper FLC is developed for minimization of fuel consumption and emissions. The fuzzy torque distribution controller selects the corresponding membership functions and rules to control the hybrid system according to the identification results of the driving cycle recognition.

As shown in Fig. 5, a FLC using the driver command, the state of charge of the energy storage, and the motor/generator speed, a set of rules have been developed, in a fuzzy controller, to effectively determine the split between the two power sources in various operation modes for $\mathrm{HEV}$ and $\mathrm{PHEV}$ with parallel configuration.

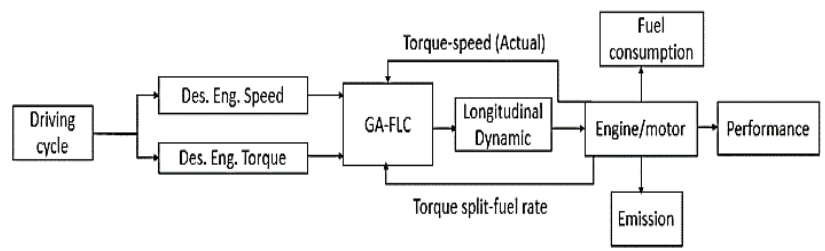

Figure 5 Schematic of GA-Fuzzy controller for HEV and PHEV

Then, in order to optimize the fuzzy logic controller, GA is utilized to tune fuzzy rules and parameters for both of the HEV and PHEV. The aim of the proposed FLC is to minimize fuel consumption and engine emissions simultaneously. This objective is the integral of fuel consumption and engine emissions over a driving cycle as follows:

$J(x)=\frac{1}{w_{1}+w_{2}+w_{3}}\left(w_{1} \int_{0}^{T_{D C}} \frac{F C}{\overline{F C}} \mathrm{~d} t+w_{2} \int_{0}^{T_{D C}} \frac{H C+N O_{x}}{\overline{H C+N O_{x}}} \mathrm{~d} t+w_{3} \int_{0}^{T_{D C}} \frac{C O}{\overline{C O}} \mathrm{~d} t\right),(1)$

where $w_{1}, w_{2}$ and $w_{3}$ are weighting factors which are representing the importance on fuel economy, total $\mathrm{HC}$ and $N O_{x}$ emissions and $\mathrm{CO}$ emissions respectively. This is one large degree of freedom, since the weights must be selected based on the design objectives. For instance, when the main objective is the minimization of the vehicle fuel consumption, the weight of $F C$ is set to 1 and the weights of emissions will be less than $1 . \overline{F C}$, $\overline{H C}+N O_{x}$ and $\overline{C O}$ are the target values extracted from the SAE-J1711 [30] emissions and fuel consumption standards, defined for normalization of objective function. In this study, the weights are considered to be equal for all the variables including the fuel consumption and emissions. $\boldsymbol{x}$ is a vector containing all parameters used to define the membership function, and $T_{\mathrm{DC}}$ is duration of driving cycle.

Table 3 PNGV standard for vehicle dynamic requirements

\begin{tabular}{|l|c|c|}
\hline \multicolumn{1}{|c|}{ Constraint } & Condition & Required \\
\hline Acceleration $\left(\mathrm{m} / \mathrm{s}^{2}\right)$ & $0 \div 97 \mathrm{~km} / \mathrm{h}$ & $\leq 12 \mathrm{~s}$ \\
\hline Acceleration $\left(\mathrm{m} / \mathrm{s}^{2}\right)$ & $64 \div 97 \mathrm{~km} / \mathrm{h}$ & $\leq 5,3 \mathrm{~s}$ \\
\hline Acceleration $\left(\mathrm{m} / \mathrm{s}^{2}\right)$ & $0 \div 137 \mathrm{~km} / \mathrm{h}$ & $\leq 23,4 \mathrm{~s}$ \\
\hline Gradeability & $88,5 \mathrm{~km} / \mathrm{h}$ for $20 \mathrm{~min}$ & at $6,5 \%$ grade \\
\hline Maximum speed $(\mathrm{km} / \mathrm{h})$ & flat ground & $>161 \mathrm{~km} / \mathrm{h}$ \\
\hline Maximum acceleration $\left(\mathrm{m} / \mathrm{s}^{2}\right)$ & flat ground & $>0,5 \mathrm{~g}$ \\
\hline Distance $(\mathrm{m})$ & in $5 \mathrm{~s}$ & $42,7 \mathrm{~m}$ \\
\hline
\end{tabular}


In addition, the vehicle longitudinal dynamic requirements are defined as constraints. The following passenger vehicle constraints are used to ensure that the vehicle performance is not sacrificed during optimization [5] (Tab. 3).

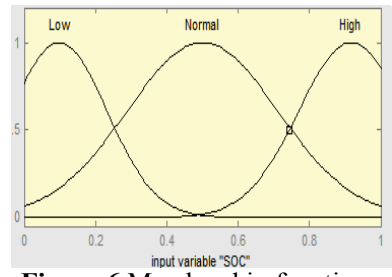

Figure 6 Membership function for SOC (input)

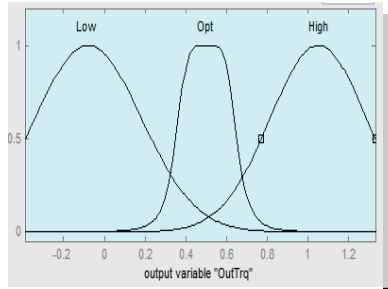

Figure 8 Membership function for output torque

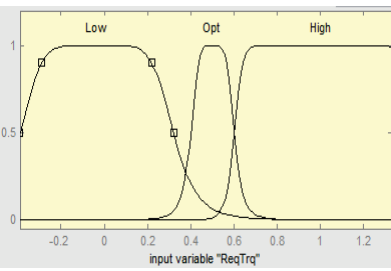

Figure 7 Membership function for input torque

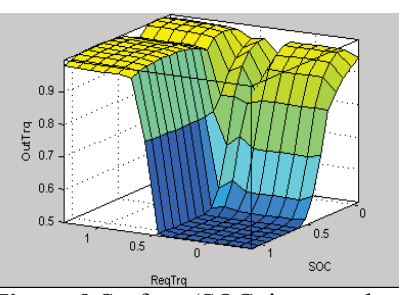

Figure 9 Surface (SOC, input and output torque)
Membership functions for SOC variation, input torque and output torque are shown in Figs. 6 $\div 9$.

\subsection{Genetic algorithm}

In order to optimize the control strategy parameters, genetic algorithm is utilized, where constraint optimization form is derived as:

$$
\operatorname{Minimize} J(x) \quad \text { s.t. } g_{i}(x) \leq 0 \quad(i=1,2,3, \ldots, n)
$$

where, $J$ and $g$ are objective and constraint functions respectively. Its parameters are listed in Tab. 4.

Table 4. Optimization parameters
\begin{tabular}{|c|c|}
\hline Value & Parameter \\
\hline 20 & Population size \\
\hline 40 & Iteration \\
\hline 0,7 & Cross over \\
\hline 0,02 & Mutation \\
\hline Uniform Selection & Selection function \\
\hline $31 / 100 \mathrm{~km}$ & $\overline{\mathrm{FC}}$ \\
\hline $0,068 \mathrm{~g} / \mathrm{mile}$ & $\overline{\mathrm{HC}+\mathrm{NO} O_{x}}$ \\
\hline $3,6 \mathrm{~g} / \mathrm{mile}$ & $\overline{\mathrm{CO}}$ \\
\hline
\end{tabular}

Combined backward-forward modelling HEV and PHEV models are utilized for implementation and simulation of the controller. Potential fuel economy improvement has been shown by using fuzzy logic, relative to other controllers, which maximize only the efficiency of the engine.

\section{Simulation in advisor}

ADVISOR was first developed in November 1994 at the National Renewable Energy Laboratory. ADVISOR was created in the MATLAB/Simulink environment [31, 32]. ADVISOR uses a hybrid backward/forward approach to simulate the vehicle dynamic performance.

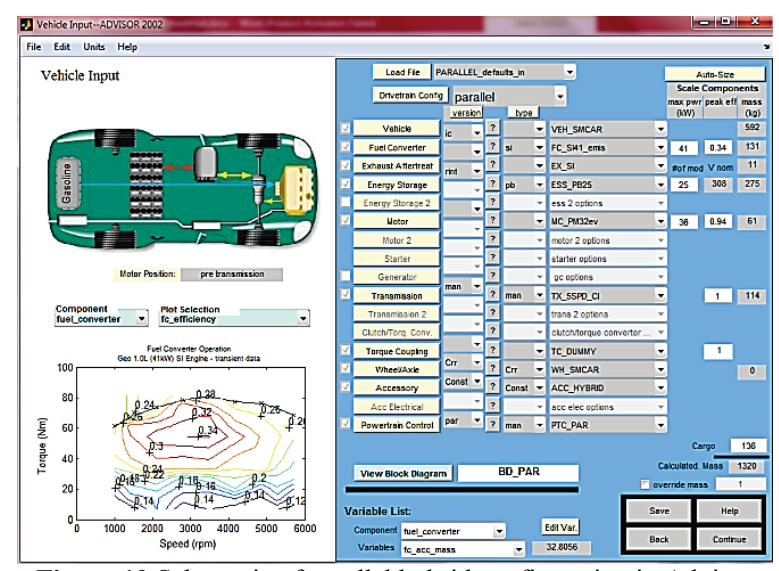

Figure 10 Schematic of parallel hybrid configuration in Advisor

Performance of ICE and EM used in the vehicle is proposed in Figs. 11 and 12 respectively. These figures illustrate the torque versus speed of ICE and EM in available operational points. An optimized control strategy based on GA-FLC is developed for HEV and PHEV and added to advisor to improve fuel efficiency, vehicle longitudinal performance and reduce the emissions.

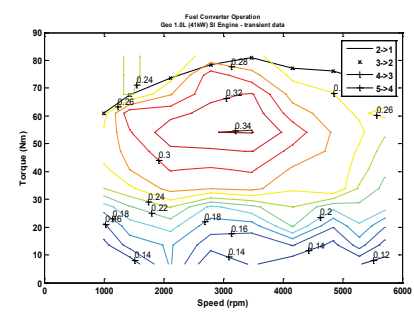

Figure 11Engine map (fuel convertor efficiency)

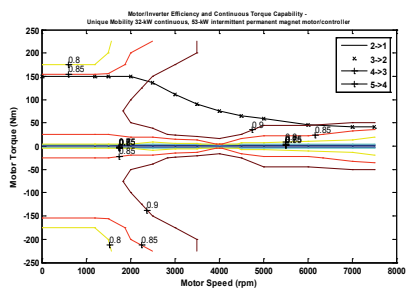

Figure 12 Motor controller efficiency

\section{Results}

In this paper a parallel HEV and PHEV model are developed in ADVISOR. Control strategy and component data are added by MATLAB/Simulink. Simulations are conducted for various driving cycle and control strategies.

In the first step, the effects of driving cycle in requested torque $(\mathrm{N} \cdot \mathrm{m})$ are evaluated in Figs. 13 and 14.

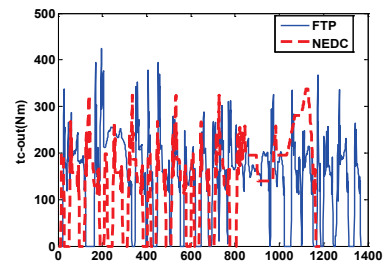

Figure 13 Effect of gearbox on output torque of the engine

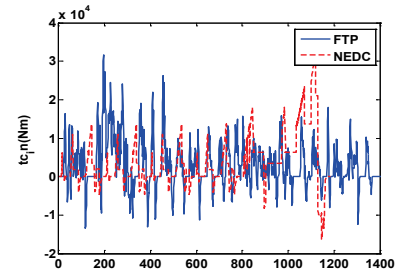

Figure 14 Effect of battery on output torque of the engine
Also, the effects of different combination of transmission (automatic/manual) and battery (Lead acid/lithium-ion) on SOC for various cycles are illustrated in Figs. 15.

The results indicate that due to intensive change in real traffic driving cycles (FTP and Teh-car) Manual gearbox improves the fuel economy and emissions. Whereas, in modal driving cycle (NEDC) automatic gearbox works more efficiently. Also, as shown, lithium- 
ion batteries for all cycles demonstrate better performance.

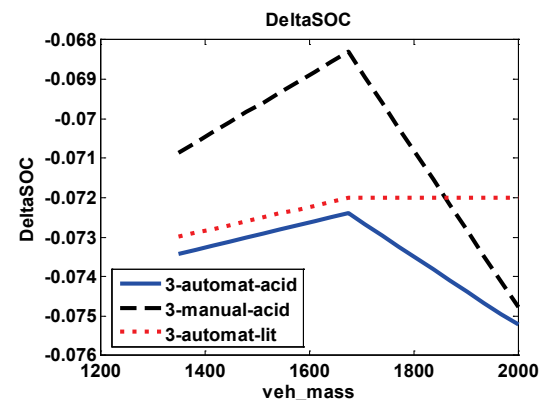

a) Delta SOC for various configuration

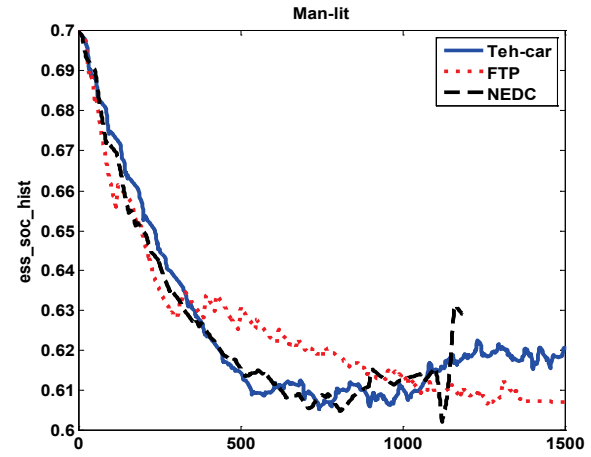

b) SOC for Manual-lithium-ion configuration

Figure 15 The effects of Configuration and driving cycle on SOC and Delta SOC

In the next stage, the performance of HEV in various optimized control strategy is compared with initial one, in various driving cycles. In order to investigate control strategy effect on HEVS performance, the normalized fuel consumption and emissions $\left(\mathrm{CO}, \mathrm{NO}_{\mathrm{x}}\right.$ and $\left.\mathrm{HC}\right)$ are illustrated in Fig. 16

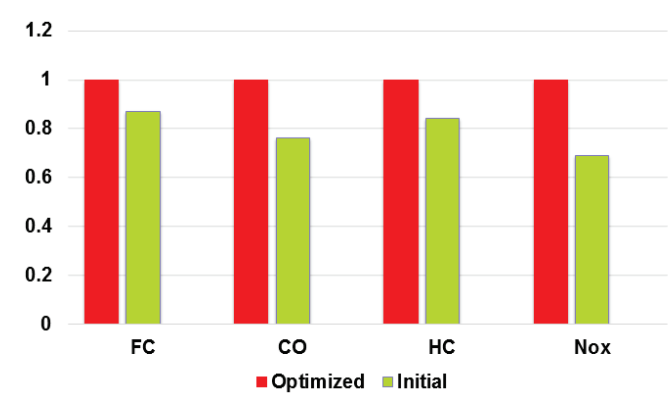

Figure 16 Comparison of fuel consumption and emissions for optimized and initial

Results demonstrate that optimization of control strategy reduces fuel consumption and emissions by about $14 \%$ and $21 \%$ in real world driving cycle.

Furthermore, in order to analyse the energy storage system, for various configuration its efficiency is illustrated in Fig. 17. Results show that lithium-ion batteries efficiency is much better than lead-acid one. Also, comparison of automatic and manual gearboxes, indicates that manual one in Teh-car improves the energy storage performance.

In the next stage, in order to evaluate the control strategies performance in real world driving condition, computer simulations are carried out at four iterations of Teh-car cycle. Gear shifting in 5 speed manual transmission during 4Teh-car cycle is illustrated in Fig. 18.

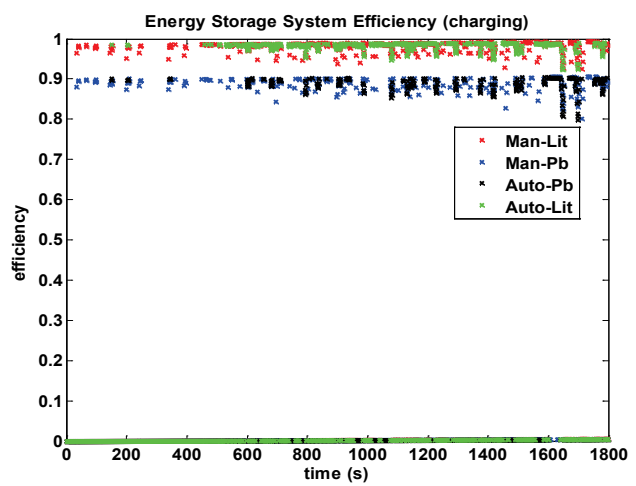

Figure 17 Energy storage system efficiency in charging mode for various configurations

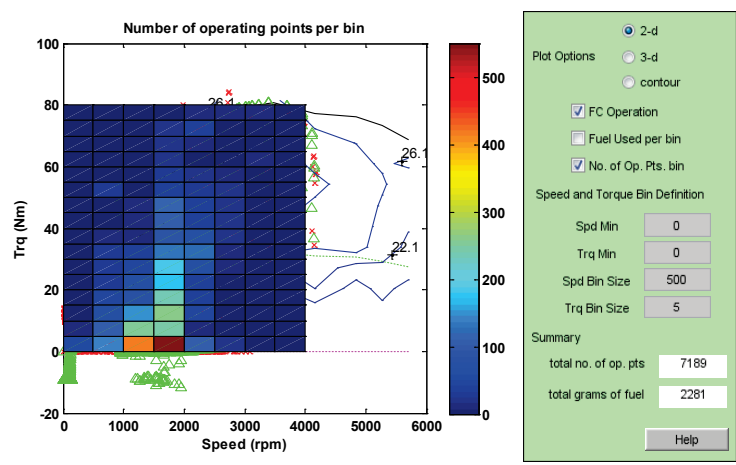

Figure 18 Fuel consumption and operation point of fuel convertor over 4 iteration of Teh-car driving cycle

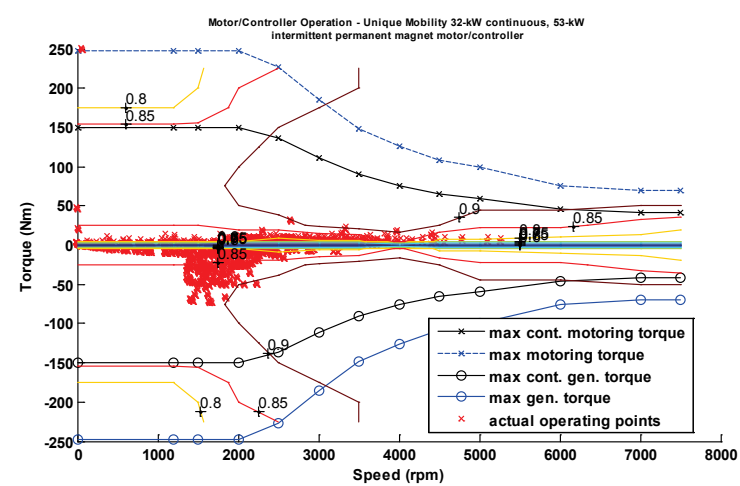

Figure 19 Motor controller operation with initial control strategy

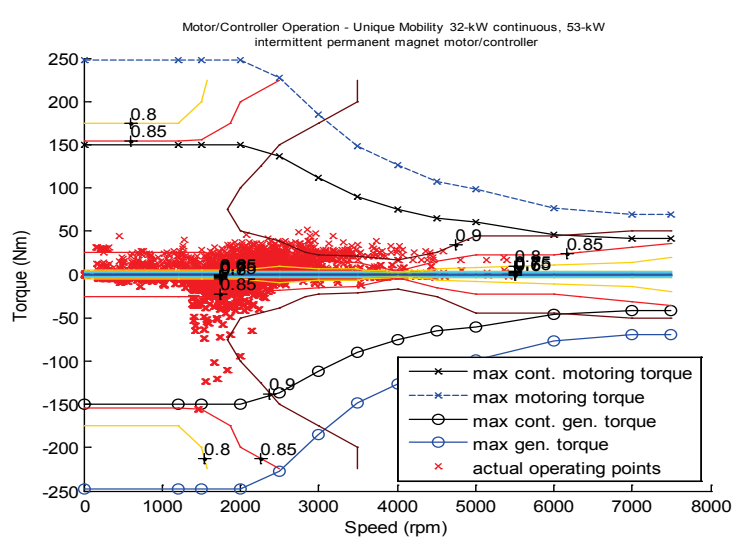

Figure 20 Motor controller operation with optimized control strategy

Performance of EM of PHEV during driving cycle for optimized and un-optimized control strategies is 
illustrated in Figs. 19 and 20. The effects of energy management optimization are clearly evident in the figures. By the optimized control strategy (GA-FLC) the operation points for EM are close to the optimized situation and their dissipation is more less than initial condition, which as well as improves energy management efficiency, results in reduction of fuel consumption and exhaust emissions.

\subsection{PHEV and HEV comparison}

Simulation results for fuel consumption and emissions are compared to PHEV and HEV according to battery state of charge. At the first stage, state of charge for PHEV with $95 \%$ and $75 \%$ initial state of charging is considered. Then in the second stage simulation is performed on HEV with the SOC of $30 \div 90 \%$. Simulation results include SOC variation, fuel consumption and emissions compared for above mentioned conditions in Fig. 21 and Tab. 5 respectively.

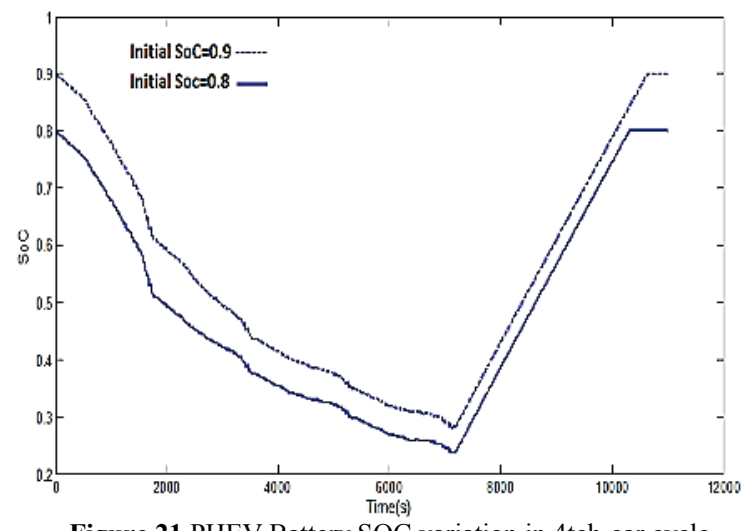

Figure 21 PHEV Battery SOC variation in 4teh-car cycle

Table 5 Simulation results and SOC effects

\begin{tabular}{|c|c|c|c|c|c|}
\hline & $\begin{array}{c}\mathrm{FC} \\
(1 / 100 \mathrm{~km})\end{array}$ & $\begin{array}{c}\mathrm{HC} \\
(\mathrm{g} / \mathrm{km})\end{array}$ & $\begin{array}{c}\text { NOx } \\
(\mathrm{g} / \mathrm{km})\end{array}$ & $\begin{array}{c}\text { Co } \\
(\mathrm{g} / \mathrm{km})\end{array}$ & $\begin{array}{c}\text { Equivalent } \\
\text { electricity } \\
\mathrm{FC}\end{array}$ \\
\hline $\begin{array}{c}\text { PHEV, Initial } \\
\mathrm{SOC}=95 \%\end{array}$ & 4,25 & 0,0282 & 0,018 & 0,560 & $\begin{array}{c}4,523 \mathrm{~kW} \cdot \mathrm{h} \\
\approx 0,781\end{array}$ \\
\hline $\begin{array}{c}\text { PHEV }, \text { Initial } \\
\mathrm{SOC}=75 \%\end{array}$ & 4,62 & 0,0312 & 0,018 & 0,582 & $\begin{array}{c}4,203 \mathrm{~kW} \cdot \mathrm{h} \\
\approx 0,7171\end{array}$ \\
\hline $\begin{array}{c}\mathrm{HEV}, \mathrm{SOC}= \\
30 \div 90 \%\end{array}$ & 6,41 & 0,0310 & 0,028 & 0,945 & - \\
\hline
\end{tabular}

This result indicated that the exhausted emissions and fuel consumption obtained of PHEV are less than HEVs. Also, the effects of SOC on PHEV performance showed that a higher initial values of SOC lead to reduction of fuel consumption and emissions.

\section{Conclusion}

In this paper the effects of real world driving cycle on fuel consumption and emissions are investigated for various control strategies. So, derivation of Tehran passenger car drive cycle is described for simulation of PHEV and HEV to evaluate their longitudinal dynamic performance. In the next step, a FLC is developed for energy management system. Then genetic algorithm is utilized for optimization of control strategy. Simulation results indicate that the proposed controller reduced fuel consumption and emissions by about $14 \%$ and $21 \%$ respectively. Also, due to using more electric power, PHEV in comparison to HEV demonstrated better performance during Teh-car driving cycle, which saves considerable amount of energy.

\section{Acknowledgments}

Corresponding author is grateful to the National Iranian Gas Transmission Company $-8^{\text {th }}$ District of Gas Transmission Operation (NIGTC-DIST8) for the support.

\section{Nomenclature}

HEV - Hybrid Electric Vehicle

PHEV - Plug-in Hybrid Vehicle

ICE - Internal Combustion Engine

EM - Electric Motor

DP - Dynamic Programming

FLC - Fuzzy Logic Controller

GA - genetic algorithm

EMS - Energy Management System

EV - Electric Vehicles

CD - Charge Depleting

CS - Charge Sustaining

SOC - State of Charge

GPS - Global Positioning System.

\section{References}

[1] Wirasingha, S. G.; Emadi, A. Classification and Review of Control Strategies for Plug-In Hybrid Electric Vehicles. // IEEE Transactions on Vehicular Technology. 60, 1(2011), pp. 111-122. DOI: 10.1109/TVT.2010.2090178

[2] Mullen, S. K. Plug-In Hybrid Electric Vehicles as a Source of Distributed Frequency Regulation // A dissertation submitted to the faculty of the graduate school of the University of Minnesota, in partial fulfilment of the requirements for the degree of doctor of philosophy, (2009).

[3] Al Alawi, B. M.; Bradley, T. H. Review of hybrid, plug-in hybrid, and electric vehicle market modelling Studies // Renewable and Sustainable Energy Reviews. 21, (2013), pp. 190-203. DOI: 10.1016/j.rser.2012.12.048

[4] Doucette, R. T.; McCulloch, M. D. Modeling the prospects of plug-in hybrid electric vehicles to reduce $\mathrm{CO} 2$ emissions // Applied Energy. 88, (2011), pp. 2315-2323. DOI: 10.1016/j.apenergy.2011.01.045

[5] Montazeri-Gh, Morteza; Mahmoodi-k, M. Investigation of the energy management and powertrain systems effects on hybrid vehicle performance // International journal of electrical and hybrid vehicles, (2015).

[6] Liu, W.; Introduction to hybrid vehicle system modelling and control, John Wiley \& Sons, Inc., 2013. DOI: 10.1002/9781118407400

[7] Nikolić, Z.; Živanović, Z. Development, characteristics and prospects of the electric vehicles // Journal of Applied Engineering Science. 9, (2011), pp. 373-382.

[8] Tie, S. F.; Tan, C. H. A Review of Energy Sources and Energy Management System in Electric Vehicles // Renewable and Sustainable Energy Reviews. 20, (2013), pp. 82-102. DOI: 10.1016/j.rser.2012.11.077

[9] Kim, T. S.; Manzie, C.; Sharma, R. Model Predictive Control of Velocity and Torque Split in a Parallel Hybrid Vehicle // Systems, Man and Cybernetics, IEEE International Conference, San Antonio, TX, (2009), pp. 2014-2019. 
[10] Song Z.; Hofmann, H., Li, J., Han, X., Ouyang, M. Optimization for a hybrid energy storage system in electric vehicles using dynamic programing approach // Applied Energy. 139, (2015), pp. 151-162. DOI: 10.1016/j.apenergy.2014.11.020

[11] Jalil, N.; Kheir, N.; Salman, M. Fuzzy Logic Control for Parallel Hybrid Vehicles // IEEE Transactions on Vehicular Technology. 10, 3(2002), pp. 460-468.

[12] Hou, C.; Ouyang, M.; Xu, L.; Wang, H. Approximate Pontryagin's minimum principle applied to the energy management of plug-in hybrid electric vehicles // Applied Energy. 115, (2014), pp. 174-189. DOI: 10.1016/j.apenergy.2013.11.002

[13] Tribioli, L.; Barbieri, M.; Capata, R.; Sciubba, E.; Jannelli, E.; Bella, G. A Real Time Energy Management Strategy for Plug-in Hybrid Electric Vehicles based on Optimal Control Theory. // Energy Procedia. 45, (2014), pp. 949-958. DOl: 10.1016/j.egypro.2014.01.100

[14] Chen, Z.; Mi, C. C.; Xia, B.; You, C. Energy management of power-split plug-in hybrid electric vehicles based on simulated annealing and Pontryagin's minimum principle // Journal of Power Sources. 272, (2014), pp. 160-168. DOl: 10.1016/j.jpowsour.2014.08.057

[15] Li, S. G.; Sharkh, S. M.; Walsh, F. C.; Zhang, C. N. Energy and Battery Management of a Plug-In Series Hybrid Electric Vehicle Using Fuzzy Logic // IEEE Trans. Veh. Technol. 60, 8(2011), pp. 3571-3585. DOI: 10.1109/TVT.2011.2165571

[16] Martínez, J. S.; Mulot, J.; Harel, F., Hissel, D.; Péra, M. C.; John, R. I.; Amiet, M. Experimental validation of a type-2 fuzzy logic controller for energy management in hybrid electrical vehicles // Engineering Applications of Artificial Intelligence. 26, 7(2013), pp. 1772-1779. DOl: 10.1016/j.engappai.2012.12.008

[17] Wu, J.; Zhang, C. H.; Cui, N. X. Fuzzy Energy Management Strategy For A Hybrid Electric Vehicle Based On Driving Cycle Recognition // International Journal of Automotive Technology. 13, 7(2012), pp. 1159-1167. DOl: 10.1007/s12239-012-0119-z

[18] Schouten, N. J.; Salman, M. A.; Kheir, N. A. Energy management strategies for parallel hybrid vehicles using fuzzy logic // Control Engineering Practice. 11, (2003), pp. 171-177. DOI: 10.1016/S0967-0661(02)00072-2

[19] Montazeri-Gh, M.; Poursamad, A. Ghalichi, B. Application of genetic algorithm for optimization of control strategy in parallel hybrid electric vehicles // Journal of the Franklin Institute. 343, (2006), pp. 420-435. DOI: 10.1016/j.jfranklin.2006.02.015

[20] Chen, Z.; Mi, C. C.; Xia, B.; You, C. Energy management of a power-split plug-in hybrid electric vehicle based on genetic algorithm and quadratic programming. // Journal of Power Sources. 248, (2014), pp. 416-426. DOl: 10.1016/j.jpowsour.2013.09.085

[21] Wu, J.; Zhang, C. H.; Cui, N. X. Fuzzy Energy Management Strategy For A Hybrid Electric Vehicle Based On Driving Cycle Recognition. // International Journal of Automotive Technology. 13, 7(2012), pp. 1159-1167. DOl: 10.1007/s12239-012-0119-z

[22] Liang, J.; Zhang, J.; Zhang, X.; Yuan, S.; Yin, C. Energy management strategy for a parallel hybrid electric vehicle equipped with a battery/ultra-capacitor hybrid energy storage system. // Journal of Zhejiang University-SCIENCE A (Applied Physics \& Engineering). 14, 8(2013), pp. 535553.

[23] http://www.autonomie.net/references/hev_26c.html, (2015).

[24] Bashash, S.; Moura, S. J.; Forman, J. C.; Fathy, H. K. Plugin hybrid electric vehicle charge pattern optimization for energy cost and battery longevity. // Journal of Power Sources. 196, (2011), pp. 541-54. DOl: 10.1016/j.jpowsour.2010.07.001
[25] He, Y.; Chowdhury, M.; Pisu, P.; Ma, Y. An energy optimization strategy for power-split drivetrain plug-in hybrid electric vehicles. // Transportation Research Part C: Emerging Technologies. 22, (2012), pp. 29-41. DOI: 10.1016/j.trc.2011.11.008

[26] Society of Automotive Engineers Surface Vehicle Recommended Practice, SAE J1711 - Recommended Practice for Measuring Fuel Economy of Hybrid-Electric Vehicles, SAE Publication, Issued March 1999.

[27] Barlow, T. J.; Latham, S.; McCrae, I. S.; Boulter, P. G. A reference book of driving cycles for use in the measurement of road vehicle emissions. // Department of Transport, Cleaner Fuels \& Vehicles, 2009.

[28] Hung, W. T.; Tong, H. Y., Lee, C. P. Development of a Practical Driving Cycle Construction Methodology: A Case Study in Hong Kong. // Transportation Research, Part D: Transport \& Environment. 12, (2007), pp. 115-128. DOI: 10.1016/.j.trd.2007.01.002

[29] Kent, H.; Allen, G. H., Rule, G. A driving cycle for Sydney. // Journal of Transportation Research. 12, (1978), pp. 147-152. DOI: 10.1016/0041-1647(78)90117-X

[30] Amirjamshidi, G.; Roorda, M. J. Development of Simulated Driving Cycles: Case study of the Toronto Waterfront Area. // Annual meeting of Transportation Research part B, 2013.

[31] Markel, T.; Brooker, A.; Hendricks, T.; Johnson, V.; Kelly, K.; Kramer, B.; O'Keefe, M.; Sprik, S.; Wipke, K. ADVISOR: a systems analysis tool for advanced vehicle modelling. // Journal of Power Sources. 110, (2002), pp. 255-266. DOI: 10.1016/S0378-7753(02)00189-1

[32] Same, A.; Stipe, A.; Grossman, D.; Park, J. W. A study on optimization of hybrid drive train using Advanced Vehicle Simulator (ADVISOR). // Journal of Power Sources. 195, (2010), pp. 6954-6963. DOI: 10.1016/j.jpowsour.2010.03.057

\section{Authors' addresses}

\section{Reza Barmaki}

Young Researchers and Elite Club,

Tabriz Branch, Islamic Azad University,

Tabriz, Iran

E-mail: barmaki.exp@gmail.com

\section{Mohammad Ilkhani}

National Iranian Gas Transmission Company,

$8^{\text {th }}$ District of Gas Transmission Operation,

Azar Shahr Road, Tabriz, Iran

E-mail: M_Ilkhani@nigc-dist8.ir

Saman Salehpour, corresponding author

Department of Mechanical Engineering, Tabriz Branch, Islamic Azad University, Tabriz, Iran

E-mail: salehpour.saman.t@gmail.com 